2016, volume 5, issue 2

Dzięcioł, P. (2016). A risk management system in insurance undertaking. Copernican Journal of Finance \& Accounting, 5(2), 73-83. http://dx.doi.org/10.12775/CJFA.2016.016

\author{
PaWet DzięClot \\ Poznań University of Economics
}

\title{
A RISK MANAGEMENT SYSTEM IN INSURANCE UNDERTAKING ${ }^{* *}$
}

Keywords: risk management, insurance undertaking, solvency II, commission delegated regulation.

JEL Classification: G20, G22, G28, G32.

Abstract: The purpose of this article is to identify and to define a role of risk management in insurance undertakings, particularly in the light of new regulations. Therefore, an obligatory of implementing a risk management system in insurance undertaking can have a negative impact on effectiveness or efficacy entity is the hypothesis of this publication. To prove or refute a hypothesis, a qualitative method and empirical research were applied. Finally, the hypothesis was proved.

\section{INTRODUCTION}

The conception of Enterprise Risk Management (ERM) focuses on entities, and these makes dependent on its own shape. According to the 'centric enti-

Date of submission: December 19, 2016; date of acceptance: January 19, 2017.

* Contactinformation: dzieciol.paw@gmail.com, Department of Insurance, Poznań University of Economics, Niepodległości 10, 60-967 Poznań, Poland, phone: +48530 843602.

${ }^{* *}$ More formal than an insurer, particularly used by European Insurance and Occupational Pensions Authority (EIOPA), Financial Conduct Authority (FCA) and European Parliament, for example in the following acts:

- Directive 2009/138/EC of the European Parliament and of the Council of 25/11/2009 on the taking-up and pursuit of the business of Insurance and Reinsurance (Solvency II), and

- Commission Delegated Regulation (EU) 2015/35 of 10/10/2014 supplementing Directive 2009/138/EC. 
tative' idea, each company defines own - different - risks, manages in others way, therefore every risk management process looks unique (Michalak, 2009, pp. 481-492). A lots of authors underline, that ERM will growth in importance, in spite of imperfections and entrance obstacles. However, Enterprise Risk Management conception would be a way to assure an effectiveness of internal and external company resources (Sasin, 2011, pp. 98-99). Nevertheless, a comparison ERM with risk management system in insurance undertakings seems exceptionally interesting.

A risk management system is definitely obligatory in Poland for insurance undertakings because of the new Insurance and Reinsurance Activity Act from $11^{\text {th }}$ September 2015 (below: Act). The legislator proclaimed a form of risk management system for insurance undertakings in chapter 3. Moreover, the Act came into force on $1^{\text {st }}$ January 2016 and Chapter 3 does not include vacatio legis. So, in every insurance undertaking should run a risk management system from beginning 2016. The definition of management system was deemed as 'a system included a risk management function, a compliance function, an internal audit function, and an actuarial function' according to the Article 3 (1) point (47) of Act. However, a proportionality of management system in dependence on character, range and complexity of insurer's activity was contained in Article 45 (2) (Ustawa o działalności ubezpieczeniowej, 2015).

\section{RESEARCH METHODOLOGY}

The verification of hypothesis is done in two steps. Firstly, in aim to clarify legal state author analyzes risk management demands of acts for insurers and legislator's risk management system. Secondly, a state of risk management in insurance undertakings has been analyzed according to empirical research. It has to underline, that gaining information about internal process and effectiveness of insurers is almost impossible. However, insurance undertakings have to fulfill BION questionnaire (Research and Supervisory Assessment) for Polish Financial Supervision Authority Office (UKNF) as well as Polish Insurance Association (PIU) published it in 2013. So the second step closes to analyze of empirical research.

In cooperation of Audit and Internal Control Commission members in Polish Insurance Association (PIU), KPMG employees and representative of Polish Financial Supervision Authority Office (UKNF), the brochure was published in 2013. It includes collective answers for questions from BION questionnaire 
(Research and Supervisory Assessment) in accordance with a state in 2012. The actual state analysis in insurance undertakings is consisted of three parts: Internal Audit Function, Compliance Function and Risk Management Function, and the last one was divided into 3 elements (Antczak et al., 2013, p. 21):

- existing of risk management function;

- risk management strategy and system;

- effectiveness and risk management review.

All of insurance undertakings (59 in Poland in 2012) furnished for BION questions, without foreign branches, so all statistic population was researched - it is definitely rare phenomenon. In effect, the source material we should assess positively.

\section{THE COURSE OF THE RESEARCH PROCESS}

Apart from duty of running risk management system in insurer, therefore the legislator requires rules of risk management, internal control and audit, as well as outsourcing in black and white, referred to Article 46 (1) of Act. Nevertheless the duty of rules above is limited to selected areas. According to Article 57 (2) of Act, risk management system includes at the minimum (Ustawa o działalności ubezpieczeniowej, 2015):

- underwriting and reserving;

- asset-liability management;

- investment risk management;

- liquidity risk management;

- concentration risk management;

- operational risk management;

- reinsurance and other risk mitigation techniques.

Moreover, in Article 57 (1) of Act it was indicated that: "risk management system includes risks which insurer has to accommodate in calculating of solvency capital requirement and these which are partially allowing for or which are excluding". We can observe, that risk management system in insurer, according to the Act, serves as menial for insurer solvency. The subject matter of solvency is presented in detail in the Commission Delegated Regulation (EU) 2015/35 of 10 October 2014 supplementing Directive 2009/138/EC of the European Parliament and of the Council on the taking-up and pursuit of the business of Insurance and Reinsurance (Solvency II). Additionally, to constitute new Act on Business of Insurance was demanding by obligatory of implement- 
ing Directive 2009/138/WE of 25/11/2009 to domestic order, which is presented in Reason for the Project of Act on Business of Insurance (Uzasadnienie Projektu Ustawy, 2015). And this is the reason why interpretation of new Act cannot be left aside Commission Delegated Regulation 2015/35 of 10/10/2014.

A risk management in insurance undertaking is still growing in value, especially by the new Act. Firstly, executive officer responsible for risk management has to know polish language currently, apart from a chief executive officer who had to (Ustawa o działalności ubezpieczeniowej, 2015, art. 50, ust. 4). Secondly, both of them are obligated to get professional experience necessitate to manage insurance undertaking (Ustawa o działalności ubezpieczeniowej, 2015, art. 50, ust. 6). Moreover, an appointing to a board has to have supervisory office assent, referred to Article 51 (1) (Ustawa o działalności ubezpieczniowej, 2015).

Insurance undertakings have to implement effective risk management system. Interestingly enough, the range of system should guarantee that economic performance. The system should include a strategy, processes and reporting procedures necessary to risk identify, estimate and monitoring, as well as risk treatment and risk reporting (Ustawa o działalności ubezpieczeniowej, 2015, art. 56, ust. 1). Here, legislator's risk management system looks similarly to ERM, by risk management process (Malinowska, 2011, p. 64). Also, we can observe Deming cycle - PDCA ${ }^{1}$, in this system, which also appear in ERM. So this fulfill principle rule of risk management process - it should be continuous and cyclic (Hadyniak, 2010, p. 32). Furthermore, the legislator demands, that insurance takings assure of effectiveness and proper risk management system integrated with organizational structure and decision-making process, including executive persons (Ustawa o działalności ubezpieczeniowej, 2015, art. 56, ust. 2). In addition, insurers are obliged to make risk management function in facilitating way for implementing system (Ustawa o działalności ubezpieczeniowej, 2015, art. 60). Whereas, insurance undertakings comply with internal model, according to Article 62, have to encompass following tasks in risk management function (Ustawa o działalności ubezpieczeniowej, 2015):

- to prepare and implement internal model;

- to verify and validate internal model;

- to prepare internal model documentation and following changes documentation;

- to analyze internal model working and to prepare reports;

${ }^{1}$ Plan - Do - Check - Act. 
- to inform a board of internal model working, to indicate areas to improve and to inform a board currently about foregoing cases.

Apart from that, insurers have to ensure risk and solvency assessment. Referred to Article 63 insurance undertaking assesses risk and solvency including (Ustawa o działalności ubezpieczeniowej, 2015):

- general needs in scope of solvency to allow for specific risk profile, risk tolerance limit approved and activity strategy;

- current compliance with solvency capital requirement and minimum capital requirement as well as requirements of technical provisions for solvency;

- deviation degree of solvency capital requirement guidelines by standard formula or full and partial internal model used, for risk profile insurance undertaking.

On the other hands, referred to Article 63 (2) a risk and solvency assessment for mutual undertakings, has extended by current compliance with solvency technical provisions demands and with preparing forecast of gross premium written for five following years (Ustawa o działalności ubezpieczeniowej, 2015).

Insurance and reinsurance undertakings are obliged to carry out own risk and solvency assessment annually or after crucial changes appearance with no delay. Furthermore, they have to inform supervisory office about effects of assessment referred to Article 63.

To sum up, previous Insurance and Reinsurance Act took into consideration only insurance risk (Ustawa o działalności ubezpieczeniowej, 2003). While new Act distinguishes a few kind of risk at least. For example insurance risk, concentration risk, operation risk, solvency risk and investment risk. Definition of management system and its working demand is the next news in Act of 2015. In comparison to preceding and actual Act, the old one brought up only "activity plan". However, the new one issues definitely the more demanding challenge.

To institute management function is a principal task for insurance undertakings. The legislator demands also that this function should be realized on adequate organizational level - a board. Additionally, insurance undertakings are obligated to ensure not only to the function, but also effectiveness of risk management system. For this reason a system range and own risk and solvency assessment was defined. Furthermore, they were burdened with the responsibility to report effects of own risk and solvency assessment, to supervisory office. We should underline that risk management system by the legislator is defi- 
nitely different from best practices and standards, and it is referred to Solvency II and Commission Delegated Regulation of 10/10/2014. The aim of risk management from the Act is solvency support to insurance undertaking, which obviously differs from enterprise risk management (ERM) goals. In addition, ERM standards (e.g. ISO 31000) base on voluntary character (ISO 31000 is not even certify), but in the Act of 11/09/2015 we meet with (bounden) duty.

A basic ratio for insurance and reinsurance undertakings are solvency capital requirement (below: SCR) according to Commission Delegated Regulation of 10/10/2014. Even though, SCR is not traditional risk ratio and it is not inform about risk level, still SCR allows for right risk module (type). Now then, to assess minimal capital requirement for right module is the main goal. And we can to simplify that it is minimal capital security level for risk taking.

In Article 37 (1) there is a risk margin (RM) formula for portfolio of insurance and reinsurance obligations (Commission Delegated Regulation of 10/10/2014). According to above, risk margin for insurance undertaking is a product of Cost-of-Capital rate and quotient of solvency capital requirement and basic risk-free rate sum. In Article 39 the Cost-of-Capital rate amount up to $6 \%$ was established. In addition, risk margin allocation runs directly with right business line - group of risk.

The formula of basic solvency capital requirement (SCR basic) was defined in Article 87. SCR basic is a root of sum of correlation rate (Corr) and SCR for module (i) and (j) product, and SCR intangibles for intangible asset risk. The value of Corr is being set by table of risk modules correlation matrix (Directive of 25/11/2009). It is not the first time of implementing mathematic methods to risk management. According to history, in 1900 the formula of 'stochastic process distribution function' was proposed by L. Bacheliera (Dionne, 2013, p. 6). In 1973 first credit risk model was created - Black and Scholes (Breccia, 2012, p. 4). And in 80s of XX century Value at Risk term was appeared, which is based on Gauss Integer Factorization (Dionne, 2013, p. 6). In addition, the solvency capital requirement is dependent to right on a risk module. Actuarial risk module is particularly extended, which consists of a lot of undermodules, e.g. hurricane risk undermodule, flood risk undermodule or civil liability risk undermodule.

There is no question, that duty of to possess right own capital for insurance undertaking is a main message of Solvency II. And their level is made dependent on business lines and modules. Unfortunately, to fulfill the duty is a success 
itself, since the European Parliament and the Council have established about one hundred formulas for solvency capital requirement according to 74 pages of Directive in 117 Articles (from 87 to 204). Probably, an increase of centralization and bureaucracy in insurance undertakings could be a dominant result. If these increase causes security increase, probably there will be more supporters. However, solvency capital requirements are not guarantors of solvency according to banks history in $21^{\text {st }}$ century, whom similarly solvency modules was proposed in Basel II and Basel III. Nevertheless, we should underline that an idea of own capital role increase, not only in insurance undertakings, is worthy of our support. But it should be proposed in easier form.

\section{THE OUTCOME OF THE RESEARCH}

The analyze of empirical research concerns to six fact-collecting questions and one subjective question about an adequacy of risk management system to insurers activity. On the graph 1 we can see collective answers for risk management function in insurance undertakings. In 2012, in 52 out of 59 insurers a station or unit responsible for irks management was functioning. However, risk committee existed in 39 entities. We need to mark, that it had been the state before Commission Delegated Regulation of 10/10/2014 and Insurance and Reinsurance Activity Act of 11/09/2015 came into force. Nevertheless, the research was done after 3 years since the pass of Solvency II of 25/11/2009, which risk management function was mentioned. 
Graph 1. Existing of risk management function in insurance undertakings in 2012

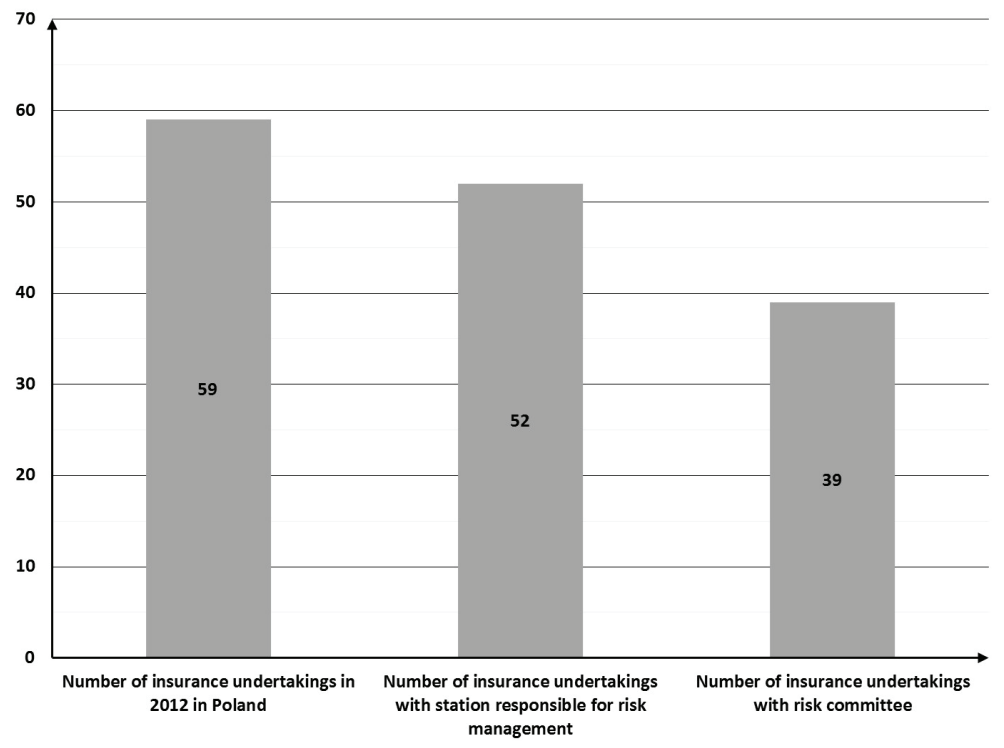

S o u r c e : own study based on: Antczak et al., 2013, p. 23.

Then, the state analysis of risk management strategy and system was done based on three criteria (graph 2). The first criterion is having risk management strategy, which has been having around $66 \%$ of insurance undertakings (39 of 59). The second criterion is written rules of risk management system, which is declared by almost $80 \%$ of insurers (47 of 57). The third criterion includes opinion about adequacy of risk management system to character, range and complexity their activity. As far as 55 insurance undertakings (93\%) indicated system adequacy, but 4 entities (7\%) pointed that absence. Unfortunately, there was no information about character of adequacy absence - positive or negative. Discussing risk management system includes first of all risk identification, risk estimation, monitoring and risk treatment. 
Graph 2. Risk management strategy and system in insurance undertakings in 2012

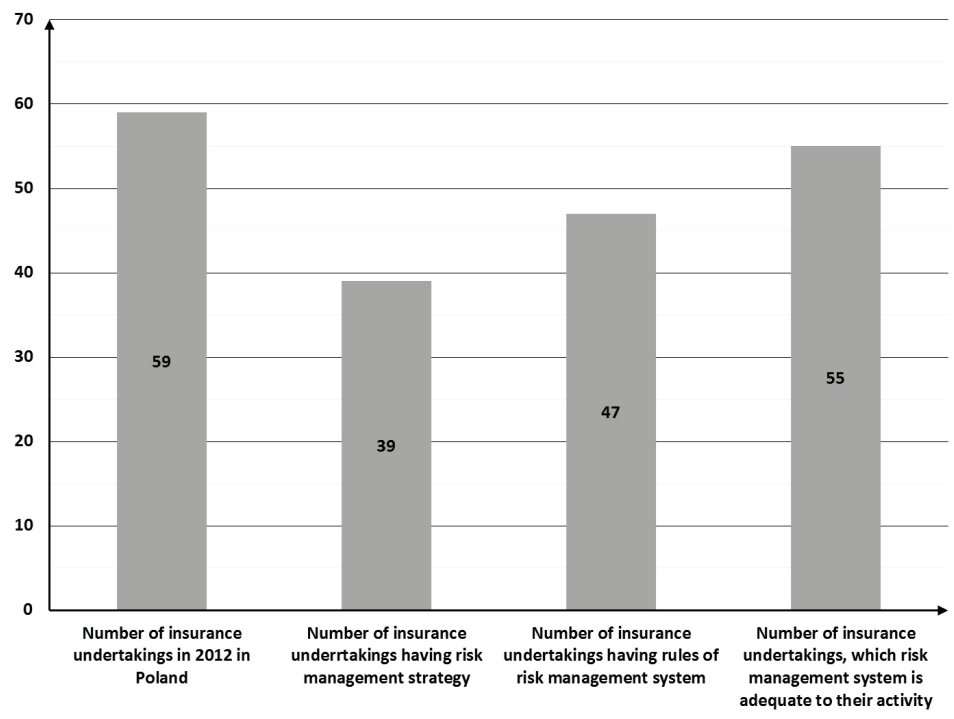

S o u r c e : own study based on: Antczak et al., 2013, p. 23.

The last one of the research consists of effectiveness risk management reviewed by insurance undertakings (graph 3). Firstly, it was indicated that over $86 \%$ of insurers were doing periodical effectiveness risk management review. Furthermore, as far as $96 \%$ of insurance undertakings confirmed that they have informed their supervisory board about the most important types of risks and control mechanisms approved.

The state analysis of risk managment in insurance undertakings concerns the time before Commission Delegated Regulation of 10/10/2014 and Insurance and Reinsurance Activity Act of 11/09/2015 came into force. Even though, we need to observe a few things. Only in $66 \%$ of insurers a risk management strategy functions. It is worth comparing to $88 \%$ of insurance undertakings which have separated station or unit. It follows that in as far as $22 \%$ of insurers function risk management unit without strategy. Moreover, only 47 entities have written rules of risk management, and 51 insurance undertakings do periodical effectiveness risk management review. So, almost $8 \%$ (4 of 51) entities do review without rules in black and white. Finally, 57 insurers informed their supervisory board about e.g. control mechanisms, but only 51 of them check ef- 
fectiveness of risk management system. Thus, over $10 \%$ of insurance undertakings accepted a system, but do not check its efficacy.

Graph 3. Effectiveness risk management review in insurance undertakings in 2012

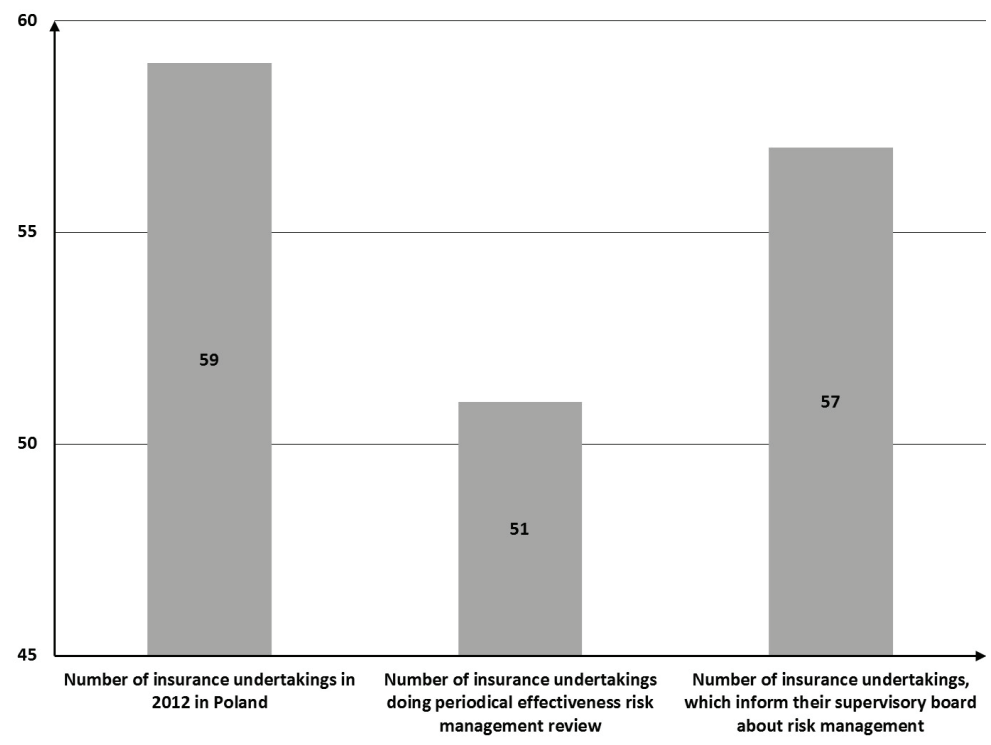

S o u r c e : own study based on: Antczak et al., 2013, p. 24.

\section{THE CONCLUSIONS FROM THE RESEARCH}

The foregoing state analysis of risk management in insurers shows that demands of Solvency II increase bureaucracy, despite that analysis focus on formal (e.g. strategy, rules or units). To confirm it, we saw that entities create station, but do not have strategy, they inform supervisory board about effects, but then not all of them check that effectiveness. Even if a risk assessment is done, some insurance undertakings do it based on established rules. We probably can summarize, that the obligatory risk management system for insurers is not match to enterprise risk management conception (ERM). Definitely, it is not necessary condition, nevertheless searching effectiveness or efficacy of obligatory risk management system is futile. The essence of that is to fulfill duty. To sum up, in consideration of the above the hypothesis was proved. Even though the hypothesis which was put forward in the article is ordinary for many people, it does not be obvious for everybody. For example, the legislator imple- 
ments the duty of risk management system for insurance undertaking, with an idea of risk management system effectiveness as well as expects economic performance (Ustawa o działalności ubezpieczeniowej, 2015, art. 56, ust. 1). However, the conclusion from the research indicates a backfire.

\section{REFERENCES}

Antczak, J., Jenerał, K., Kornacka, E., Lenard, J., Popadyniec, R., Rajca, B., Sambora, B., Stasiak, W., Szambelan-Bakuła, E., Tomaszkiewicz, A., Wawrzeniecka, A., Wiącek, T., Chądzyński, A., Kowalski, R. (2013). Audyt - Compliance - Zarządzanie Ryzykiem - Aktuariat. Modele współpracy w zakładach ubezpieczeń. Warsaw: Polish Insurance Association.

Breccia, A. (2012). Default risk in Merton's model, http://www.bbk.ac.uk (accessed: 19.01.2017).

Commission Delegated Regulation (EU) 2015/35 of 10/10/2014 supplementing Directive 2009/138/EC of the European Parliament and of the Council on the taking-up and pursuit of the business of Insurance and Reinsurance (Solvency II), Journal of Laws from 2015 L. 12.

Dionne, G. (2013). Risk Management: History, Definition and Critique, Cirrelt, https:// www.cirrelt.ca/ (accessed: 19.01.2016).

Directive 2009/138/EC of the European Parliament and of the Council of 25/11/2009 on the taking-up and pursuit of the business of Insurance and Reinsurance (Solvency II), Journal of Laws from 2009 L. 335

Hadyniak, B. (2010). Zarządzanie ryzykiem w przedsiębiorstwie. In B. Hadyniak, J. Monkiewicz (Ed.), Ubezpieczenia w zarządzaniu ryzykiem przedsiębiorstwa. Warsaw: Poltext.

Malinowska, U. (2011). Charakterystyka kluczowych koncepcji zarządzania ryzykiem w przedsiębiorstwie. In S. Kasiewicz (Ed.), Zarządzanie zintegrowanym ryzykiem przedsiębiorstwa w Polsce. Warsaw: Wolters Kluwer.

Michalak, J. (2009). Ryzyko społeczne a ochrona ubezpieczeniowa - kilka propozycji nieortodoksyjnych. In J. Handschke (Ed.), Studia ubezpieczeniowe. Poznań: Poznań University of Economics.

Sasin, R. (2011). Ewolucja koncepcji ERM. In S. Kasiewicz (Ed.), Zarządzanie zintegrowanym ryzykiem przedsiębiorstwa - kierunki i narzędzia. Warsaw: Wolters Kluwer.

Ustawa z dnia 11 września 2015 r. o działalności ubezpieczeniowej i reasekuracyjnej, Dz.U. [Journal of Laws] 2015 poz. 1844.

Ustawa z dnia 22 maja 2003 r. o działalności ubezpieczniowej, Dz.U. [Journal of Laws] 2003 nr 124 poz. 1151.

Uzasadnienie Projektu Ustawy o działalności ubezpieczeniowej z dnia 28 kwietnia 2015 r., https://legislacja.rcl.gov.pl/ (accessed: 10.12.2016). 
